\title{
Introduction: Work and Labour Relations in Global Platform Capitalism
}

\section{Julieta Haidar and Maarten Keune}

\section{INTRODUCTION}

Since the 1990s, and in particular since the 2008 crisis, digital platforms have progressively ascended to the centre of contemporary capitalism, giving rise to so-called platform capitalism (Srnicek 2016). Platform capitalism is an authentically global phenomenon as around the world platforms have come to play a major role in social networking, retail, business services, delivery of food and other products, domestic and care work, streaming, the development of artificial intelligence, transport, etc. Global platform capitalism is epitomised by a group of very large transnational companies like Alibaba, Facebook, Alphabet, Amazon, Tencent or Uber. And then there is a large, and ever-growing group of other, smaller platforms, some also with a global reach and others focusing on specific groups of countries. Through their rapid growth, digital platforms are increasingly shaping social relations, consumption, work and labour relations around the globe.

In this volume, we present an analysis of work and labour relations in global platform capitalism. We focus our analysis on labour platforms - digital platforms that organise labour processes by matching labour providers (mainly self-employed workers) with clients and consumers. Labour platforms charge rents over the fees paid through the platform and use algorithmic management methods to exercise disciplinary control, to a varying degree, over task allocation and performance (Gandini 2019).

Labour platforms can be divided into online and offline platforms (De Stefano 2015). Online platforms connect a multiplicity of clients and individual workers through the internet, with work being done remotely. The scope of online platforms is global, transcending geographic boundaries and creating atomised global labour markets. Some of these platforms require complex services or 'macrotasks' with higher skill levels, such as translation or design (e.g. Upwork, Workana). Others cover a multiplicity of simple 'microtasks' or 'click work' (e.g. Clickworker, Amazon Mechanical Turk) such as the catego- 
risation of pictures, transcription of speech, participation in surveys, etc., that require lower skill levels.

Offline platforms connect clients and customers with workers who perform their tasks physically in a given geographic space. Some services are developed in public spaces, such as passenger transport (e.g. Uber, Cabify) and delivery (e.g. Deliveroo, Glovo) and others in private spaces, such as home repair (e.g. IguanaFix, Jobin) or domestic and care work (e.g. Helpling, Aliada). Offline platform work generally involves physical tasks like driving or cleaning; however, the workers are also continuously interacting through apps with the platform to receive orders or instructions, accept or decline tasks and receive evaluations.

Labour platforms have become significant sources of controversies, tensions and ambiguities. On the one hand, they have become important sources of work and income. This tendency seems only to be strengthened by the COVID-19 pandemic as many have retreated into their private homes and predominantly have digital social interaction, increasing demand for the services of labour platforms. Also, the economic crisis and job losses resulting from the pandemic make labour platforms a possible shelter for unemployed workers. In addition, the platforms claim that they provide high levels of autonomy and flexibility to workers regarding when and how much they work. On the other hand, it is often argued that the work that labour platforms create is precarious and exploitative, that they raise the control of capital over workers to new heights, and that platform workers lack legal protection and collective representation.

In this volume, we discuss these controversies, tensions and ambiguities surrounding labour platforms theoretically and empirically, and situate them within the broader development of global capitalism. The volume brings together authors from different parts of the world, takes a global perspective and studies a selection of continents, countries and types of online and offline platforms. It is divided into three main parts. The first is a largely theoretical part that situates platform work in the wider context of contemporary capitalism and includes chapters by Nick Srnicek, Mariano Zukerfeld and Petar Marčeta. The second part discusses labour platforms from the perspective of the international division of labour as well as their embedding in local labour markets and contains chapters by Janine Berg and Uma Rani, Vili Lehdonvirta, Isis Hjorth, Helena Barnard and Mark Graham, and Wing-Fai Leung, Premilla D'Cruz and Ernesto Noronha. The third part focuses on the labour process and labour relations and incorporates chapters by Simon Joyce and Mark Stuart, Cora Arias, Nicolás Diana Menéndez and Julieta Haidar, Kurt Vandaele, and Graciela Bensusán and Héctor Santos.

In this introduction we present in five sections our main propositions, which can be summarised as follows: (1) labour platforms are at the frontier of cap- 
italist development, comprising both important continuities and meaningful novelties; (2) labour platforms generate new dependencies and a new international division of labour between the global North and South; (3) labour platforms are capital's latest attempt to increase control over the labour process; (4) labour platforms are built on and foster the ideal of the entrepreneurial self; and (5) labour platforms are riddled with tensions between dependency and autonomy, the shape of which influences the extent and ways in which workers organise. In discussing these five propositions we make ample use of the subsequent chapters of this volume that analyse various aspects of them in detail.

\section{LABOUR PLATFORMS AND THE DEVELOPMENT OF CAPITALISM}

The emergence and growth of labour platforms cannot be understood as driven by the availability of digital technologies but are an expression of longer-term tendencies we can observe in the global political economy. Labour platforms represent profound innovation that embodies the frontiers of capitalist change, but they are also products of earlier developments and demonstrate continuities with the past. In this section we provide a discussion of several major and closely interrelated aspects of capitalist development of the last few decades that are relevant in this respect. We present the main arguments in a concise way here, while in the subsequent sections their most salient features are discussed in detail.

To begin with, the rise of labour platforms is part and parcel of the development of capitalism as a mode of production that continuously seeks to optimise the labour process. Where in the first post-WWII decades Fordism was the dominant mode of organising the labour process, since the 1970s, in the post-Fordist era, a series of new types of management and work organisation have been devised (Boyer \& Durand 1997; Lepadatu \& Janoski 2020). These range from lean production, Toyotism and flexible specialisation, to McDonaldization, project-based organisations and agile management. They all in their own way attempt to optimise the labour process, some emphasising standardisation, external labour flexibility, low wages and tight control and others focusing on increasing autonomy, internal flexibility, skills development and career planning.

Labour platforms can be considered one of the frontiers in this process of optimisation and the latest manifestation of the capitalist labour process. As will be discussed in more detail below, they combine the latest digital technologies with their own specific organisational, managerial and discursive strategies to optimise the use of labour. This includes unilateral and untransparent algorithmic management methods to strengthen efficiency, flexibility and control and the circumvention of the wage relationship to reduce costs and 
risks and again to increase flexibility. They also involve the construction of workers as entrepreneurs, emphasising their autonomy and responsibility for their own success and fostering intense competition between them.

Labour platforms also constitute the next level in the ongoing process of global fragmentation of economic activity, aiming to exploit differences in labour and other costs between countries and continents, and to optimise value chains. Since the 1970s we can observe the decline of the large integrated firm in the global North, which progressively started to subcontract and outsource production to optimise cost efficiency and profits and reduce risks. Over the years, this process of fragmentation acquired a decisively global character as capital started to massively offshore activities to geographical locations more advantageous in particular in terms of labour costs (Gereffi 2011, 2014). Massive offshoring took place first in manufacturing but gradually also in a wide range of services, resulting in complex and fragmented global value chains in which predominantly Northern capital orchestrates the global distribution of profits and risks (Gereffi 2014).

Labour platforms take this fragmentation a step further. This is especially true for online labour platforms which facilitate the outsourcing and offshoring of a growing range of service activities not to companies but to an infinite pool of freelancing and competing individuals across the globe. They allow firms and individual clients to access individual workers on all continents in an instant and to seek out the most favourable price-quality combinations. As will be discussed in the next section, this results in a new international division of labour which includes elements of the pre-industrial putting-out system.

In their own way offline platforms also contribute to a new international division of labour, not because work crosses borders but because many of the workers on offline platforms are migrants, coming from other countries. Although they are often overqualified for the work they do, for migrants that have a hard time finding jobs, platform work has the advantage of low entry barriers and the promise (although not necessarily the reality) of earnings that compare favourably to other job opportunities they have access to in the host country. In this way, labour platforms offer migrant workers much-needed opportunities to improve their livelihoods while simultaneously reproducing discrimination and degrading working conditions (van Doorn et al. 2020; van Doorn 2017).

Apart from the optimising and fragmenting of existing activities, labour platforms also play a role in capitalism's drive to bring more and more areas and activities under capitalist relations (Silver 2003), or, as Streeck (2017) phrases it, to 'ultimately commodify everything'. Labour platforms have a threefold importance in this striving for commodification. One is that platform work, generally not subject to employment and social protection regulations, often replaces or crowds out work that previously did enjoy such 
protection, thus recommodifying labour (Marčeta in this volume; Aloisi 2015). As will be discussed in the next section, this applies in particular to the global North where it contributes to the growth of precarious work. Another is that labour platforms commodify labour previously not subsumed by the capitalist mode of production (Marčeta in this volume). This can concern previously non-commodified activities as well as the incorporation of geographical areas or groups of persons that were previously largely outside the reach of the capitalist mode of production. Finally, labour platforms, like all other platforms, engage in the continuous accumulation of data about all aspects of their activities. There is a lively debate concerning the extent to which this data is commodified and whether it is part of a process of value creation or rather value appropriation (Fuchs 2014; van Doorn \& Badger 2020). Two chapters in this volume contribute to this debate and do so from different perspectives: Srnicek argues that platforms mainly engage in value appropriation through rents instead of value creation, whereas Zukerfeld does argue that platforms produce value but claims that there are different types of exploitation through which capital obtains a surplus value at the expense of exploited actors, which do not necessarily occur in the context of labour relations.

The accumulation of data is also closely related to a further aspect that has been vital for the development of labour platforms, that is the financialisation that gradually got its grip on global capitalism from the 1970s (Deutschmann 2011; van der Zwan 2014). In the previous decades, growth rates in the global North had started to decline, resulting in less profitable investment opportunities for investment capital. At the same time, high savings rates, an increased money supply, low interest rates and public policy liberalising the financial sector fostered a swift increase in available equity and venture capital and investors desperately started to look for new and highly profitable investment opportunities, a tendency which sharpened after the financial crisis of 2008.

Labour platforms promise to provide such opportunities, in two different ways. On the one hand, because of their capacity to capture value by charging rents for each transaction that the platform facilitates (e.g. each delivery, Uber ride, executed click task or completed translation). Here the interest of investors is in the novel and lean business model of labour platforms which makes them potentially very profitable ventures. On the other hand, as mentioned above, labour platforms continuously accumulate data about their own processes, markets, customers, etc. This data is first of all used to improve their own operations but, more importantly, they potentially represent value in a broader but yet indeterminate sense as well:

[...] whereas the value of this monetary rent can be dynamically determined by the platform, the value of data rent is fundamentally indeterminate insofar as it derives from speculative and performative practices. Platforms engage in constant 
data accumulation because of the potential value this data, once processed by their analytics software, might embody or give rise to [...] Yet captured data also attract venture capital and grow financial valuations, to the extent that investors expect data-rich platform companies to achieve competitive advantages by creating data-driven cost efficiencies, cross-industry synergies, and new markets. (van Doorn \& Badger 2020: 3)

As a result, venture capital and other investors have shown great interest in the platform economy and massive amounts of capital have been invested in labour platforms and in platform companies in general, in particular after the financial crisis (Langley \& Leyshon 2017; Kenney and Zysman 2016). It is important to underline that these are essentially rentier-type investments that do not engage in value creation but in rent and value appropriation. In this sense, platforms are exemplary for financialised capitalism in which rentiers, i.e. finance owners and financial institutions, have become core actors in the economy, not contributing to productive investments but strongly increasing their income, at the expense of stagnating real wages and increased household debt (Streeck 2017; van der Zwan 2014; Standing 2016). The fact that these massive investments in platforms have a non-productive character also explains why the enormous growth of many platform companies has not been accompanied by accelerating economic growth in the global North; indeed, they may rather undermine growth by extracting value from the productive economy (Srnicek in this volume).

Finally, the rise of labour platforms was facilitated by the fact that over the previous decades neoliberalism had established itself firmly as the quasi-hegemonic governmentality of capitalism in most parts of the world, even though in a geographically variegated way (Harvey 2005; Brenner et al. 2010; Peck 2013). Two dimensions of neoliberalism are particularly important for the understanding of the emergence and growth of labour platforms. One, which will be discussed in more detail below, is the rise of the ideal of the entrepreneurial self (Bröckling 2013) fostering the continuous construction of workers as entrepreneurs, autonomous subjects who are responsible for their own destiny.

The other is that the neoliberal era is increasingly becoming a state of post-democracy, in which both economic and political power is '[...] increasingly being exercised by international business interests ranging at will over transnational territories beyond the reach of nation-states - the level at which democracy remained largely trapped' (Crouch 2016: 71). Large corporations are less and less subject to the rules of the market, and rather strive for monopolistic or oligopolistic status; they are also less and less subject to the rules of democracy, freely moving their financial assets across borders, escaping regulations of some countries and imposing their own rules in others (Crouch 
2004, 2016). This is particularly true for platform companies, today the largest, most globalised and most powerful companies (Drahokoupil and Piasna 2017; Degryse 2019). ${ }^{1}$ They have become the main example of capitalism unbound. Existing regulations and regulators often do not have the capacity to deal with the digital nature of in particular online platforms, which means they easily transcend the nation-state and seem to escape geography. Similarly, the novelty of their activities and business models often means that there are no clear standards to govern them, allowing for unchallenged self-regulation by the platforms. And where regulators try to enforce compliance from platforms, the latter invest heavily in lobbying and court battles to protect their interests.

This also applies in terms of labour and social security regulations (ibid.). Online platforms in particular easily avoid (national) regulations since these do not foresee digital employment relations in which client and worker may be located on different continents and digital platforms are the entity closest to the figure of the employer. Deciding which regulations apply where and how to enforce them presents an array of serious problems, as does the question of how to organise online platform workers through trade unions or other organisations. Consequently they often only have access to the protective standards and arbitration or mediation procedures which the platforms themselves establish (if any). This leaves the workers without real protection against precarious employment conditions and abusive practices.

Offline labour platforms, operating in defined geographical spaces where it is clear which labour and social security regulations should apply, engage in extensive political lobbying and fierce court battles in order to evade such regulations. Their main strategy is to deny that they are employers of the workers working for their platform, and in this way refusing workers employee status and the protective labour regulations and social security rights this status brings (Bensusán and Santos in this volume; Marčeta in this volume; De Stefano, 2015). Platforms like Uber or Foodora constantly lobby politicians and are involved in court cases around the world to try and safeguard their non-employer status. On top of this, the strategies of trade unions to organise and protect offline platform workers are still in their infancy (Arias et al. in this volume; Vandaele in this volume).

In this way, the neoliberal hegemony has created an ideological and regulatory environment in which labour platforms can lower costs and increase flexibility and control by placing themselves outside the reach of labour and social security regulations. This connects neoliberalism to the starting point of this section, i.e., capitalism as a mode of production that continuously seeks to optimise the labour process, and exemplifies the interconnections between the various aspects of capitalist development and the ways in which they have favoured the rise of labour platforms. 

AND SOUTH

With the expansion of platform capitalism, labour platforms have become global phenomena. However, as demonstrated in several chapters in this volume (Vandaele; Bensusán and Santos; Berg and Rani; Lehdonvirta et al.; Lueng et al.), their local manifestations and impacts vary due to the uneven global distribution of capital, the structural and institutional features of local labour markets and the international division of labour. To capture this tension, in this section we examine two main issues. One is how labour platforms shape the relationships between the global North and the global South, in particular through online labour platforms. The other is the specific impact of labour platforms on local labour markets.

Concerning the relationships between the global North and South, we identify two quite distinct but not mutually exclusive perspectives. The first focuses on exploitation and underlines how Northern capital utilises labour platforms as a new way to get access to ever-cheaper labour and to exploit workers in the global South. The second centres on opportunities and emphasises that labour platforms offer countries and workers in the South valuable prospects for development.

The exploitation perspective starts from the observation that most of the online labour platforms are financed by capital from the global North, most of the demand for labour on these platforms also originates in the North, while most of the work is done by workers from the global South (Lehdonvirta et al. in this volume; Graham et al. 2017). In this way, online labour platforms increase the dependency of the South on Northern capital and make it vulnerable to its whims. They also orchestrate a new international division of labour in which workers in the South are digitally subordinated to capital and clients in the North.

Lueng et al. (in this volume) argue that the global character of these platforms results in a new international putting-out system of labour (NIPL). Whereas historically the putting-out system of home-based artisanal workshops preceded the movement of work to the factories of the industrial era, labour platforms are reversing this development and are moving work back to the homes of individuals (Kenney \& Zysman 2016), principally in the global South. The NIPL allows the clients from the North to reduce the costs of labour, management, supervision, equipment and real estate and to transfer many of the risks traditionally borne by employers and investors onto the shoulders of Southern workers.

Additionally, nominal hourly rates in the South are often substantially lower than in the North (Lueng et al. in this volume; also Berg and Rani in this 
volume). Workers from the South suffer from 'liabilities of origin', as clients act according to country stereotypes, facilitated by the respective information platforms present on the workers (Lehdonvirta et al. in this volume). For example, clients from the North expect workers from the South to accept lower rates than their Northern counterparts, even when they have the same skills and experience. This discriminatory behaviour goes against the supposedly meritocratic nature of platform work, where earnings should above all depend on one's own capacities and commitment. Indeed, equal human capital does not mean equal earnings in the global platform labour market (ibid.).

Moreover, workers in the South often accept lower rates because of the lack of better opportunities in their local labour market. This is further strengthened by the fact that labour demand on online platforms far outstrips labour supply (ibid.), fomenting competition between workers and causing downward pressure on pay rates. Indeed, many platform workers (from South and North) would like to work more hours but are confronted with the limited availability of work. However, this affects workers from the South more as platform work is often their only or main source of income, while in the North it is generally an additional source of income to complement insufficient wages in the main job (Berg \& Rani in this volume). As a result, workers from the South have fewer alternative opportunities and less bargaining power. Furthermore, in many cases they have to adapt their working hours to the requirements of their clients in the North, leading to extensive night work. And on top of these disadvantages workers from the South are also confronted with racist language and remarks in their interactions with Northern clients as well as competing workers from the North (Lueng et al. in this volume).

The opportunities perspective instead argues that online labour platforms offer workers and countries in the global South important opportunities to make good use of capital from the North. A number of governments in the global South view such platforms as a way to strengthen their economy and labour market and therefore as an important element of their development strategies (Berg \& Rani in this volume; Soriano \& Cabañes 2020). They argue that labour platforms offer an important new source of income and a way to mitigate the brain-drain caused by the outward migration of well-educated workers. In this view, labour platforms can substantially reduce the need to attract productive capital from abroad and all the concessions this may require.

Also, platform workers in the South see several positive sides to online platforms. To restate a point made above in a more optimistic way, for the more highly skilled workers in particular hourly pay is often substantially better than the earning opportunities on their local labour markets, even if it might be below that of workers from the North. Moreover, when pay rates are converted to purchasing power parity, online platform workers in the South may actually earn more than their Northern counterparts (Berg \& Rani in this volume). 
Apart from pay, other positive aspects underlined by platform workers are the (real or fictious) flexibility and autonomy concerning when, where and how much they work, opportunities to build networks with new contacts all over the world, and opportunities to learn new skills (Lueng et al. in this volume).

In our view, these two perspectives both offer useful interpretations and are not mutually exclusive. They show that the North-South relations created by online labour platforms are full of contradictions and tensions. Online platforms are largely populated by workers from the global South but orchestrated by capital from the North, leading to exploitation, dependency, inequalities and discrimination. At the same time, they offer workers from the South earning, learning and autonomy opportunities that they lack in their local labour markets. These opportunities are the reason that workers often express their satisfaction with platform work, despite its exploitative character.

The other issue that we want to discuss here is the differential effect labour platforms, both on- and offline, have on local labour markets. As mentioned above, a key characteristic of labour platforms is that they (attempt to) circumvent local labour market and social protection institutions. They create informal employment which, according to the ILO (2018) is employment that is not, in law or in practice, subject to national labour legislation, income taxation, social protection or entitlement to employment benefits. It is important however to underscore that the level of informality differs dramatically between the global North and South. Whereas in 2016, 61.2 per cent of global employment was informal employment, in Western Europe, USA, Canada and Australia informality was below 20 per cent, which contrasts with 53.1 per cent in Latin America, 68.2 per cent in Asia and the Pacific and 85.8 per cent in Africa (ibid.).

The differences in levels of informality stem from the (partial) decommodification of labour in the North labour during Les Trente Glorieuses of the post-WWII era. In this period, labour market-related risks were to an important extent collectivised through protective employment and social regulations and strong trade unions (Esping-Andersen 1990). However, in recent decades the trend has been one of recommodification, as employers seek to evade or weaken protective institutions, and trade unions have been losing strength in most countries and sectors (Streeck 2017; Keune \& Pedaci 2020; Doellgast et al. 2018). This is manifested by the growing use of, among others, temporary contracts, zero-hour contracts, on-call contracts, bogus self-employment, and outsourcing. Labour platforms can be considered the latest manifestation of this process of recommodification, contributing to the further weakening of labour protection (Marčeta in this volume). At the same time, the recommodifying effect of platform work in the North is limited since it is more often a complement to a formal job and a way to earn additional income in the context of stagnation of wage growth and increasing labour market insecurity. 
In most of the global South, decommodification did not take place to the same extent and was often limited to parts of the public sector and large enterprises. Precarious work lacking protection is a structural feature of the labour markets in the South. Labour platforms consequently do not necessarily contribute to the weakening of protection but largely reproduce the low level of protection of the historically large informal sector (Bensusán et al. 2017). Or as Lueng et al. (p. 146, in this volume), discussing online platform work in India and China, phrase it: 'Unfortunately, workers' rights and collective bargaining are not well developed in either country, and therefore, with online employment, Upworkers are as vulnerable as their offline counterparts'. Platform work in the South can therefore more easily be interpreted as simply another source of (informal) work and income, without the connotation of recommodification. Consequently, the novelty of platform work in the South resides not so much in its precarious nature but, as mentioned before, in the alternative employment opportunities it provides as well as the possibilities for better earnings than those available on the local labour market.

Labour platforms create a new international division of labour and affect local labour markets in a variegated way along the North-South divide. However, it is noteworthy that they do not seem to challenge the traditional gender division of labour. In this respect, Berg and Rani (in this volume) show that inequalities between men and women, to the detriment of the latter, transcend geography. Women in both global regions emphasise their need or preference to work from home, indicating a persistence of the traditional gender division of labour in which domestic work and care responsibilities predominantly fall on women's shoulders. On top of this, women earn less than men from platform work in both global regions, suggesting that, instead of transforming such fundamental cultural traits, labour platforms tend to reproduce them.

Thus, labour platforms are global phenomena but geography continues to matter, both in the relationships these platforms create between the global North and South and in the way they affect local labour markets. In the following sections we will discuss in more detail the commonalities and geographical specificities around three core dimensions of labour platforms: the labour processes and algorithmic management methods workers are subject to, the process of constructing the subjectivity of the workers according to the ideal of the entrepreneurial self, and the challenges they pose in terms of collective workers' organisation. 


\section{PLATFORMS AS MODES OF ORGANISING AND} CONTROLLING THE LABOUR PROCESS

The definition of platforms as companies that organise labour processes enables us to recognise the existence of processes of valorisation of capital and of asymmetrical social relations between capital and labour (Joyce \& Stuart in this volume). On the basis of these premises we discuss how labour platforms organise and control the labour process underlining three characteristics. The first is that platforms constitute a hybridisation of different historical attempts by capital to close the existing gap between the productive capacity of labour power and its effective application in the service of capital. The second is that these efforts, in platform capitalism, are permeated by a new form of management, so-called 'algorithmic management' (Rosenblat \& Stark 2016; Möhlmann \& Zalmanson 2017). The third is that the control exercised by the platforms leads to the obliteration of the distinction between work and life, or between working time and free time, intensifying the tendency towards the real subsumption of society under capital.

With regards to the first characteristic, over the course of capitalist history, capital has developed different attempts to capture the productive capacity of labour power. We can distinguish at least three attempts which have been combined at different points in history (Vercellone 2020). The first is the technical division of labour (principally through Taylorism), based on expropriating workers' knowledge, codifying it and transferring it to capital, and then assigning tasks existing of specific standardised times and methods of completion. The second starts from accepting the impossibility of completely capturing the cognitive dimension of labour and eliminating the margin of workers' autonomy. Faced with this dilemma, the manager promotes the voluntary engagement of the workers' knowledge and time in the manager's interests. The third consists of the implementation of various techniques to evade the wage relation and the responsibility for managing the time and activities of the workers. Among these techniques are: the piecework distinctive of mercantile capitalism and early industrial capitalism, and today's use of the figure of self-employment.

In the organisation of platform work, these three attempts to more effectively capture labour power to the benefit of capital appear in a mixed form. They are adapted and redesigned according to the particular characteristics of the different platforms. Concerning the first attempt, we observe a revival of the technical division of labour in an emerging 'neo-Taylorism' or 'digital Taylorism', a useful concept with which to describe not only new modes of workplace surveillance, control and deskilling, but also '... how a variety of forms and combinations of software and hardware as a whole allow for new 
modes of the measurement, standardisation and quantification, decomposition and surveillance of labour - often through forms of (semi-) automated management and control' (Altenried 2020: 149). This concept applies to some extent to all platform work, but it is particularly relevant when considering microtask labour performed on online platforms. As with classic Taylorism, workers perform repetitive microtasks which are part of a larger process they are unaware of and disengaged from, like identifying images, symbols, sounds, or transcribing fragments of conversations which contribute to developing artificial intelligence. Amazon Mechanical Turk (AMT) explains it in this way: 'MTurk enables companies to harness the collective intelligence, skills, and insights from a global workforce to streamline business processes, augment data collection and analysis, and accelerate machine learning development'. ${ }^{2}$ While digital Taylorism does not represent an entirely new form of control, it does have some unique digital characteristics. Contrary to classic Taylorism, microtask platforms do not necessarily determine when a worker works or how much time is spent on a task. They rather rely on the extensive reserve army to permanently maintain a sufficient supply of labour for the tasks at hand. By virtue of the technology, the labour is performed by thousands of crowd workers who cooperate 24 hours a day around the world, while the monitoring techniques characteristic of Taylorism are obscured by algorithmic management. Therefore, as the 'mechanical Turk' metaphor suggests, the platform is designed to sell living labour as if it were machinic labour (Altenried 2020).

The second historical attempt, i.e. the promotion of the voluntary engagement of the workers, is expressed in platform capitalism by invoking the figure of the entrepreneurial self (see the following section for a more detailed analysis). The platforms project an image of the autonomous entrepreneurial self, unencumbered by bosses, who freely manages her choices concerning what work she performs, when she does it and how much time she spends on it. Workers do often enjoy these sides of platform work (even though autonomy is largely fictitious in many cases). This is particularly so in the case of macrotasks, where the platforms and their clients require the highest degree of involvement of the worker and all her knowledge and skills, which results in an appeal to the worker's interest in learning and developing skills and knowledge.

However, some argue that real learning opportunities are limited as digital workers are,

(...) in many cases kept at arm's length, unable to access information about the wider chain their labour forms part of. Those digital workers are unsure of what function their tasks serve; what the meaning of tasks are, or how their work is put into use by end-clients. Furthermore, only some digital workers were able to articulate or make qualified guesses as to how their clients derive value from the labour they performed. (Graham et al. 2017: 152) 
The latter view, combined with the ever-present control and evaluation by platforms, enables us to identify a certain 'Taylorisation of cognitive labour' which limits skills upgrading.

Finally, the third attempt to control labour power is expressed through the evasion of the wage relation by appealing to the figure of self-employment and the incorporation of systems of payment uncoupled from working hours. Through the figure of self-employment and the terms and conditions that the workers are obliged to accept each time they connect to the app, the platform companies make efforts to conceal the existence of employment relations, and at the same time they avoid and allow their clients to elude business risks.

For online macrotasks this is realised in the form of payment per project, in which workers engage their knowledge and affects. In the case of online microtasks and a majority of work on offline platforms (e.g. food delivery and passenger transport), the intensification of the appropriation of labour power is produced through piecework payments. Along these lines, what Marx recognised towards the end of the 19th century is reasserted:

Given piece-wage, it is naturally the personal interest of the labourer to strain his labour-power as intensely as possible; this enables the capitalist to raise more easily the normal degree of intensity of labour. It is moreover now the personal interest of the labourer to lengthen the working-day, since with it his daily or weekly wages rise. (Marx 2018: 390)

Our second characteristic of the way in which labour platforms organise and control the labour process is that the above-discussed attempts to maximise the capturing of labour power are modernised and permeated by algorithmic management. This is a new mode of managing labour power, in which surveillance, supervision and, ultimately, control are carried out by algorithms. The uniqueness of this type of management in the era of digital technology consists in the fact that the monitoring and evaluation of the workers is performed in an individualised, continuous and remote way. Furthermore, the algorithmic technology enables a refinement and concealment of the processes of standardisation, codification and appropriation of knowledge in its diverse forms.

As we noted in the first section, one of the distinctive elements which characterises platform capitalism is the gathering and systematisation of enormous volumes of data. With regards to workers, this implies a continuous surveillance and manipulation of the information on their profiles and performances. This is achieved through the use of biopolitical technologies, such as GPS tracking, the periodic capture of identities by requesting 'selfies' (for offline platforms), or through information about the private sphere such as data related to civil status, illness, photos and videos of the workers' faces and bodies (for online platforms). This, as is mapped out by Lehdonvirta et al. 
(in this volume), grants the platforms the power to reintroduce discriminatory practices along the lines of class, gender and ethnicity.

This data gathering also enables the companies to supervise and assess the workers' performance, making use of a large volume of evaluations completed both by the companies themselves and by customers, clients and providers. Some online platforms include tests and other qualification measures or, in the case of more complex tasks, allow clients to control workers via random screenshots or keystroke counters (Altenried 2020). In the case of offline platforms, customers and providers produce evaluations and in some cases publish comments online about the workers' performance.

As has been amply documented (Rosenblat \& Stark 2016; Shapiro 2018; Haidar 2020), such evaluations, materialised in points and rankings, are converted into complex systems of rewards and punishments. While this is more widely documented for the offline platforms, where the workers can suffer temporary or permanent 'deactivations' (euphemisms for suspensions and dismissals) this also occurs on the online platforms. In effect, microtask workers depend on positive ratings from the task requesters in order to receive more work in the future, so a rejected task means not only potential loss of payment, but potentially restricted access to further work (Altenried 2020). The continuous monitoring and ratings are designed to control the labour process, and therefore the process of valorisation: the algorithms establish tariffs, bonuses, commissions, regulations and procedures to follow. In some cases the platforms attain control through strict rules and regulations. In others this is achieved in an indirect or induced way through the 'gamification of work'; in other words the generation and monitoring of conduct through gaming mechanisms, using images with a strong visual impact which set targets and offer rewards to the participants with the aim of maximising their performance.

Likewise, the almost complete digitalisation of the relationships between platforms and workers, and the high versatility and low transparency characterising the algorithms, express the asymmetry of power between the two. This disparity is intrinsic to the relations between capital and labour; the unique quality that the platforms contribute is the digitalisation of existing asymmetries as a mode of concealing their existence. The metaphors of the 'black box' (Pasquale 2015; Moore \& Joyce 2020) and the 'shadow employer' (Gandini 2019) imply that the notion of control or directive power is concealed and transferred to the impersonal authority of the system.

Finally, the third characteristic of the way in which labour platforms organise and control the labour process is that they blur the boundaries between working hours and free time. This happens in different ways. Several of the offline platforms offer bonuses for those who work during certain hours (in delivery and transport), while online platforms encourage working during the 
waking hours of clients in the global North which do not coincide with the normal working day of those living in the southern hemisphere.

Likewise, the particular dynamics of the platforms cause workers to be in a constant state of attention in order to snap up new job offers and to dedicate hours of their free time to engaging in unpaid work constructing their public profiles and searching for the next job. Also, and more significantly, they use their time, energy and emotions to become entrepreneurial and productive subjects, attuned to the demands of clients and the figure of the entrepreneurial self. In this way, the division between work and life, or between working hours and free time, is effaced, intensifying the tendency towards the real subsumption of society under capital. This tendency draws us closer to the dystopia pursued by the capitalist political project: a worker wholly dedicated to capital.

\section{THE ARTIFACTUALITY OF THE PLATFORM WORKER: THE ENTREPRENEURIAL SELF}

Just as we identified algorithmic management as a historic form of controlling the labour process and subordinating knowledge to the processes of valorisation of capital, it is possible to identify in the construction of the platform worker a compounded form of the entrepreneurial self; that is, the aspirational figure par excellence of hegemonic neoliberal governmentality in contemporary capitalism.

The ideal of the entrepreneurial self started to develop with the discontent of workers after the rebellions of May 1968 in France, and the rejection of the discipline of labour under the Taylorist-Fordist type of organisation. Along these lines, Bröckling (2013; see also Foucault 1997) maps out a genealogy of entrepreneurialism and observes that it constitutes an offshoot of the varied manifestations of the post-1968 counterculture which, in spite of their anti-capitalist impulse, can be seen in hindsight as laboratories for the gestation of an entrepreneurial attitudinal orientation. Outlining a genealogy of entrepreneurialism by tracing its roots to the counterculture of independence enables us to understand its success: the entrepreneurial self could only become a hegemonic figure because it reflected a collective desire for greater autonomy, personal realisation and non-alienated labour (Bröckling 2013).

The management literature of the 1990s radicalised this programme, both inside and outside companies, with self-management manuals and methodical, success-oriented lifestyles, aimed at self-optimisation. In the sphere of production this translated into new participatory models of organising work as forms of building consent, or in Burawoy's (1979) terminology, 'voluntary submission' in the workplace. In the development of platform work this ideal was strengthened by an array of techniques of government through which, as Foucauldian approaches to neoliberal governmentality point out, individual 
liberty is constructed (i.e. is not natural) and recharacterised as autonomy (Dean 1999; Rose 1999).

The platforms in all their diversity are permeated by this conception. They discursively present themselves as an opportunity for workers to increase their autonomy, organise their own time, earn income and obtain other benefits (learning, self-development, meeting people, constructing networks), without bosses or restrictions, and according to the individual investment that each worker-entrepreneur makes of her time, skills, efforts, motivations and emotional commitment. This individualisation has resulted in the radical responsibilisation of the workforce, based upon an extreme version of self-interested individualism (Fleming 2017).

This discourse is accompanied by a heterogeneous group of performance technologies (monitoring and surveillance, rewards and penalties, etc.), which contribute to fabricating and enhancing autonomous subjects and promoting highly individualised and demanding working practices: self-discipline, self-realisation, and competition with oneself and other workers. Therefore, as suggested in the previous section, the reconciliation between life and work proclaimed by the movement which challenged alienation in the 1960s has materialised for platform workers as the subsumption of all aspects of their life under work.

The complexity of this phenomenon derives from the fact that the platforms' discourses and technologies of performance constitute practices of government as well as the promotion of workers' self-government, which in this articulation combine notions of liberty and submission (Dean 1999). In the figure of the entrepreneurial self this is expressed as an extremely powerful 'real fiction' (Realfiktion), which sets and keeps in motion a continuous process of modification and self-modification of subjects (Bröckling 2013).

These constructions of subjectivity, with all their ambivalences and tensions, have particular characteristics according to the geographical specificities in which the online and offline platforms are embedded and operate. This involves the incorporation of other determinations and subjects of government that transcend the platform companies: political-juridical interventions (whether direct or indirect) that establish the conditions of free, entrepreneurial and economically rational conduct of individuals; and the cultural constructions that are associated with a process of neoliberalisation structured according to class, gender and racial interests.

With regards to this situated configuration, we can empirically observe that online platform workers emphasise the benefits of working from home, without bosses, and above all being able to autonomously organise their working hours and free time. This is, as mentioned earlier, especially valued by women, which seems to indicate a reproduction of patriarchal models 
of unequal distribution of domestic labour and care work between men and women.

The geographically embedded character of the configuration of platform work is expressed clearly by Leung et al. (in this volume), who note how in China and India the entrepreneurial spirit and individualism promoted by the platforms represent relatively novel values imported from the West that are enthusiastically embraced by the middle classes, particularly young recent graduates. In India, the authors observe, the platforms represent a movement away from the feudalist ethos which permeates most workplaces in that country, fostering exploitative and sycophantic conduct and practices.

These brief considerations about how platform work and workers' subjectivities are constructed in harmony with the ideal of the entrepreneurial self, with its returns and advantages, both real and imaginary, enable us to spotlight the ambivalent and conflictual character of labour platforms. In this section we have chosen to emphasise how the idea of the autonomous worker is constructed from a positive axiology. However, the 'real fiction' of the entrepreneurial self also produces contradictory feelings. Feelings of self-realisation, autonomy and satisfaction are accompanied by feelings of frustration, impotence, discontent and injustice. These representations are informed by the physical, mental and emotional fatigue provoked by the gamification, the technological dehumanisation, and the unilateral, shifting and opaque nature of algorithmic decisions.

Although, as Bröckling (2013) points out, simulation and stimulation intermingle until they can no longer be differentiated. What remains unclear is how far individuals maintain the fiction, how difficult it is for them to sustain it, and what counteracting experiences they can endure. Along these lines, it now remains for us to analyse how these ambivalences and tensions impact on the construction of organisational responses from workers.

\section{WORKERS' ORGANISATION AS A FIELD OF TENSION}

The question of platform workers' organisation and resistance has been studied from a variety of perspectives. One is labour process theory, which takes on a dual dynamic in which control always sparks resistance (in a latent or active form). Along these lines, Joyce and Stuart (in this volume) show how three broad categories of platform management methods (algorithmic management, pay and wider forms of regulation) each include dimensions of control, which are associated with three types of resistance: micro-level fiddles and individual resistance, informal collective actions, and actions organised by unions or other worker representation and advocacy groups, on a more formal basis. 
Others analyse resistance from the perspective of the challenges that platform work poses for workers' representation, placing special emphasis on trade union responses. For example, Vandaele (in this volume) reasserts the categories of power resource theory (structural, associational, institutional and societal power) and two ideal type representation approaches: the logic-of-membership, if efforts are concentrated on worker organisation, and the logic-of-influence, if the responses are rooted in the institutional logic of national systems of industrial relations. Similarly, Arias et al. (in this volume) study workers' organisation and strategies from the perspective of trade union traditions: rank and file type organisation, with horizontal and combative features, on the one hand, and hierarchical, vertical, bargaining-oriented organisation, on the other.

These interpretations make important contributions towards analytically arranging the repertoires of collective action, demands and forms in which the workers organise in the context of platforms. However, besides this, it is necessary to develop an approach which gives an account of the ambivalent character of platform work. Epistemologically this involves incorporating an analysis of feelings of injustice and discontent, as well as the libidinal component, i.e. satisfaction and benefits.

Indeed, the tensions around platform work constitute a necessary component with which to understand workers' organisation: how are the tensions between subjection and freedom expressed in their forms of organisation? To what extent do these tensions affect workers' demands and repertoires of action? How far do they permeate political meanings and projections? The hypothesis animating these questions is that organisational responses are an expression of the particular tensions between subjection and freedom that characterise platform work.

By organisational responses we understand forms of organisation, repertoires of collective action, along with the demands and political projections that the workers construct. We can hypothesise that the construction of organisational responses depends on varying articulations between multiple determinations: the forms of control exercised by the platforms, the power resources of workers and unions, union traditions and strategies, and governmental interventions, all corresponding to specific geographical configurations of the labour market, culture and institutions. Here we want to draw particular attention to the connections established between the tensions around the subjection/ freedom dyad and the organisational responses that are constructed along with their claims, forms of collective action and perspectives.

To this effect, we distinguish four organisational responses as inductively constructed Weberian ideal types, which reflect varying combinations of satisfaction and defence of the autonomist ideal, and feelings of injustice and recognition of the existence of relations of subordination and dependence. 
These ideal types, by definition, are not expressed in practice in a pure form, but in a variety of combinations.

First, we can identify the responses we describe as 'pro-status quo', which most tightly cleave to the ideal of the entrepreneurial self and which defend the full development of autonomy. Constructed on the basis of the satisfactions and benefits provided by the platforms, the workers engage in limited actions with the sole aim of improving the conditions in which they operate on the labour market.

Here we find the participation of workers in different forms of digital associativism, social networks and forums where they share information and tips about how to earn a higher income and avoid sanctions. Examples are online clickworkers who warn other workers about clients who pay badly or fail to pay; app-based taxi drivers who report on changes in the algorithms and ways of circumventing them; food delivery workers who share information about which neighbourhoods have higher demand, etc. Sharing information and tips can also be accompanied by coordinated action, as is the case with clickworkers who act together to manipulate the configuration of algorithmic preferences or who develop browser plugins (e.g. Turkopticon) which help workers to increase their access to better-paying tasks (Joyce and Stuart, in this volume).

While these actions are collective, no questioning of the founding logic of the platforms arises, no demands or claims are presented to the platforms, and there is no construction of a political subject, but rather an interest in improving their conditions without disrupting the status quo. However, that does not detract from the construction of solidarities tending to equalise, in a partial and limited way, the asymmetries of information and power between workers and platforms. These solidarities also counteract the relationship of competition that exists between the participants who, from the representation of the entrepreneurial self, are conceived of as rivals competing for the market.

A second set of responses can be described as 'reformist' and are the paroxysmal expression of the tensions which permeate the organisation of work and the workers in their subjectivity, for whom satisfaction, desire for autonomy, discontent and rejection of arbitrary algorithmic practices are enmeshed. This set of responses is diverse; it includes a wide repertoire of action, with varying demands, organisational forms and meanings. The main objective is to partially reform the functioning of and relationship with the platforms, without abandoning the vindication of sovereignty over their use of time and organisation of their own lives.

To illustrate these expressions, we can refer to the diversity of responses from food delivery workers. Although these workers often joined the platforms having been seduced by promises of freedom in their activities, expectations turn to discontent when faced with what are viewed as abusive practices that 
violate the contract of trust between parties. In many cases, workers coordinate actions and jointly oppose the company that takes advantage of them. How and with what meanings these demands and actions develop from the experience of these contradictions is uncertain, sinuous and heterogeneous.

In some experiences the workers organise into associations which demand that the established terms and conditions be respected or improved, a demand which reframes the relationships between workers and platforms in terms of a commercial contract between equal parties. Other demands are often added to these which are aimed at improving income and working conditions on the platforms: rate increases, minimum payment for working hours, health coverage and insurance, etc. The demand for recognition of an employment relationship does not take precedence, nor do attempts to sign collective bargaining agreements, which for many workers represent a threat to the benefits of platform work.

The repertoires of action and institutional forms that their organisation take are as heterogeneous as the demands that motivate them. Here, although not exclusively, the logic of membership takes precedence: in some cases the workers are self-organised (such as 'Riders for Rights' in Spain), while in other cases they are organised by rank and file trade unions, or are supported and absorbed by larger unions (for a detailed analysis of the European case see Vandaele's chapter). Therefore, both self-organisation (as a priority) and trade unions can channel demands which strive to win improvements and labour rights, while maintaining the status of independence.

Similarly, the demands are expressed through a variety of repertoires of action, many of them associated with digital technology. These include twitter hashtag campaigns, virtual boycotts and campaigns ('Justice4Couriers' in Finland, \#BrequeNosApps in Brazil, \#EnTuPedidoVaMiVida in Mexico) through which they aim to build solidarity with customers, as well as demonstrations and strikes by disconnecting or logging off. Emblematic of this type of response are the wave of food delivery worker strikes which began in London in the summer of 2016 and which spread to the rest of the UK and other cities in continental Europe (Joyce and Stuart in this volume), the global Uber strikes that took place in May 2019 with heightened levels of coordination across the United States and other countries (Johnston 2020), and more recently the international wave of food delivery worker strikes protesting the lack of protection they have suffered in the context of the pandemic. These strikes are dissociated from the routine mechanisms of conflict which are characteristic of the classic dynamics of strike/negotiation. Given the low levels of workplace bargaining power resources, the log-offs are more an expression of dissatisfaction and a demonstration of latent power than part of a strategy aimed at achieving more thorough transformations. However, it is possible to infer that the strikes, with the commitments, solidarities and proposals they 
mobilise, contribute substantively to the construction of a worker identity in the context of the platforms.

A third type of response can be characterised as 'standardisation', in which workers organise on the basis of a recognition of the asymmetry of power in relation to the platforms, their exploitative character, and the search for a resolution which would minimise the tension between freedom and subjection, in favour of a recognition of the standard employment relationship. Here the idea of autonomy is called into question, it is experienced as a deception which generates more disadvantages than benefits, since the platforms control and discipline the workers without granting them any type of labour rights or social protection.

On this basis, the main demand raised is to change the status of the workers from independent contractors to employees, and for bargaining over collective labour agreements. The repertoires of action include demonstrations and strikes, but also the use of legal channels through which the workers seek a legal recognition of their status. Here, the construction of links with political authorities and local businesses takes on a greater role, as they can contribute towards constructing social dialogue or regulating labour relations.

As might be expected, the institutional forms which better adapt to these demands are the unions, and the logic which prevails is that of influence. However, self-organisation can also direct demands along this path, generally with the support of trade unions. One expression of this phenomenon is the establishment of works councils with trade union support in cities in Austria and Germany (Vandaele in this volume; Johnston 2020).

It is perhaps for this type of response that geographical characteristics occupy a more important position, given that the characteristics of the labour markets, actors and labour relations institutions are more decisive. Thus, it is not surprising that it is in the Scandinavian countries, with more cooperative labour relations and strong unions, where collective bargaining about platform work is more advanced (ibid.).

Finally, a fourth type of organisational response can be described as a 'disruption'. Here, as with the previous type, there is a recognition of asymmetrical and exploitative relations, but unlike the previous type it does not translate into renouncing the idea of autonomy and a demand for regulation. Instead, the vindication of autonomy along with the workers' ability to organise their labour process independently of the companies predominates, thus disrupting the prevailing platform model.

Along these lines, rather than taking action and presenting demands to the platforms, the workers maximise their cooperative efforts. Therefore, the organisational form par excellence is cooperative platforms. Swiftly constituted and with an uncertain future, Vandaele (in this volume) identifies at least ten cooperatives in different European countries which use the software devel- 
oped by the federation of bike delivery workers' cooperatives 'Coopcycle'. This association defines itself as a mutualist, solidary and autonomous strategy inspired by the solidarity model of social security in which one contributes according to capabilities and receives according to needs. The political horizons in this sense are presented as more radical, not seeking to negotiate with platforms but rather to transcend them with forms that combine autonomism and mutualism.

It remains unclear whether the organisational responses will tend to converge in the same way that the business models of platforms companies have done in recent years. Neither is it clear which are the most appropriate alternatives to effectively confront the enormous power imbalances that characterise the relations between workers and platforms. What emerges however, as a noteworthy feature, is that the demands, actions, forms and projections are complex and permeated by the same contradictions that characterise platform work and platform workers. Taking an optimistic view of the ambivalences, tensions and quasi-aporetic character of platform work, rather than acting as a constraint they can be seen as fertile territory for action and transformation.

\section{CONCLUSIONS}

Labour platforms constitute a dynamic and growing global phenomenon that accelerated after the 2008 crisis and has been further speeded up by the COVID-19 pandemic, given the increase in the demand for platform services and the unemployment-fuelled supply of labour. They raise a series of questions about capitalism, work and labour relations which we have discussed in a concise form in this introduction, and which will be examined in more detail throughout the rest of this volume. The following conclusions emerge from our discussion.

One is that the expansion of labour platforms is not an isolated, technology-driven process but one that can only be understood as part of the broader process of capitalist development and change. It represents an intensification of earlier trends of optimisation, (re)commodification and global fragmentation of labour processes and has been dependent on the ongoing financialisation and neoliberalisation of capitalism. Related to this, labour platforms are global phenomena but geography continues to matter, both in the relationships of dependence and inequality they create between the global North and South and in the way they affect local labour markets.

Furthermore, labour platforms constitute a hybridisation of different historical attempts to close the gap between the productive capacity of labour power and its effective application in the service of capital. The main instrument of control here is algorithmic management: the control exercised by the platforms leads to the obliteration of the distinction between working time and free 
time, intensifying the tendency towards the real subsumption of society under capital. This is further strengthened by the construction of the platform worker as a form of the entrepreneurial self, autonomous and free. However, the 'real fiction' of the entrepreneurial self produces contradictions between feelings of self-realisation, autonomy and satisfaction on the one hand and feelings of frustration, impotence and injustice on the other.

Indeed, labour platforms create continuous ambivalences and tensions which impact on the construction of organisational responses from workers, reflecting varying combinations of satisfaction and defence of the autonomist ideal, and feelings of injustice and recognition of the existence of relations of subordination and dependence. We distinguish four ideal-typical organisational responses that can be used to depict workers' responses: pro-status quo, reformist, standardisation, and disruption, each representing a particular combination.

As this introduction has shown, the algorithmic technology, the construction of competitive individualised subjectivities and the insistence on the figure of the self-employed worker allow the platform companies to deploy their business model and to reinforce power asymmetries in relation to the workers. Taking into account the magnitude of these asymmetries and the complexity and versatility of the platform model, the recurrent question is how to protect platform workers? Much of the corresponding debate focuses on the question of whether the figure of self-employment fits the actual situation of platform workers and how to better regulate platform work.

These are important issues as protective regulations can reduce power asymmetries and employee status may confer a range of employment and social rights to platform workers. However, considering the widespread (or growing) presence of precarious work in the labour market in general, bringing platform work within the scope of protective legislation will not by itself be sufficient to tackle the disadvantageous position of platform workers. From a regulatory perspective, this requires a broader debate around how to guarantee the effective application of existing regulations and the possible need for supplementary norms in general or for platform workers in particular.

To improve the position of platform workers, apart from the question of regulation, additional attention should be given to the even more complex but important challenges related to algorithmic management, workers' subjectivities and inequalities: how to get a grip on the unilateral, ever-changing and opaque digital management mechanisms? How to deal with gender inequality in labour platforms, including unequal responsibilities for unpaid domestic and care tasks? How to construct a collective workers' identity? And, most importantly, how to construct sufficient power resources to counteract the power of the platforms? Responding to these questions requires a profound debate among scholars, platform workers as well as in the broader working-class and 
labour movement. With this book we hope to make our contribution to this debate.

\section{NOTES}

1. According to a PwC report, among the top ten of the largest companies by market capitalisation in mid-2020, seven were predominantly platform companies: Apple, Microsoft, Amazon, Alphabet, Facebook, Tencent and Alibaba. See https://www .pwc.com/gx/en/audit-services/publications/assets/global-top-100-companies -june-2020-update.pdf

2. See www.mturk.com

\section{BIBLIOGRAPHY}

Aloisi, A. (2015), 'Commoditized Workers: Case Study Research on Labor Law Issues Arising from a Set of on-Demand/Gig Economy Platforms', Comparative Labor Law \& Policy Journal, 37 (3), 653-690.

Altenried, M. (2020), 'The Platform as Factory: Crowdwork and the Hidden Labour behind Artificial Intelligence', Capital \& Class, 44 (2), 145-158.

Bensusán, G., Eichhorst, W. \& Rodríguez, J. M. (2017), Las transformaciones tecnológicas y sus desafios para el empleo, las relaciones laborales y la identificación de la demanda de cualificaciones. Santiago de Chile: CEPAL.

Boyer, R. \& Durand, J.-P. (1997), After Fordism. London: Macmillan Press.

Brenner, N., Peck, J. \& Theodore, N. (2010), 'Variegated Neoliberalization: Geographies, Modalities, Pathways', Global Networks, 10 (2), 182-222.

Bröckling, U. (2013), El self emprendedor. Santiago de Chile: Universidad Alberto Hurtado.

Burawoy, M. (1979), Manufacturing Consent: Changes in the Labor Process under Monopoly Capitalism. Chicago: The University of Chicago Press.

Castells, M. (1996), The Rise of the Network Society. Vol. I of The Information Age: Economy, Society and Culture. Malden, MA and Oxford, UK: Blackwell.

Crouch, C. (2004), Post-democracy. Cambridge: Polity Press.

Crouch, C. (2016), 'The March Towards Post-Democracy, Ten Years On', The Political Quarterly, 87 (1), 71-75.

De Stefano, V. (2015), 'The Rise of the Just-In-Time Workforce: On-Demand Work, Crowdwork, and Labour Protection in the Gig-Economy', Comparative Labour Law \& Policy Journal, 37, 471-503.

Dean, M. (1999), Governmentality. Power and Rule in Modern Society. London: Sage.

Degryse, C. (2019), 'Introduction', in I. Daugareilh, C. Degryse \& P. Pochet (eds), The Platform Economy and Social Law: Key Issues in Comparative Perspective. Brussels: European Trade Union Institute (ETUI).

Deutschmann, C. (2011), 'Limits to Financialization: Sociological Analyses of the Financial Crisis', European Journal of Sociology, 52 (3), 347-389.

Doellgast, V., Lillie. N. \& Pulignano, V. (2018), Reconstructing Solidarity: Labour Unions, Precarious Work, and the Politics of Institutional Change in Europe. Oxford: Oxford University Press.

Drahokoupil, J. \& Piasna, A. (2017), 'Work in the Platform Economy: Beyond Lower Transaction Costs', Intereconomics, 52 (6), 335-340. 
Esping-Andersen, G. (1990), The Three Worlds of Welfare Capitalism. Princeton, NJ: Princeton University Press.

Fleming, P. (2017), 'The Human Capital Hoax: Work, Debt and Insecurity in the Era of Uberization', Organization Studies. Accessed at https://doi.org/10.1177/ 0170840616686129

Foucault, M. (1997), Ethics: Subjectivity and Truth. (Essential Works of Michel Foucault, 1954-1984. Vol. 1). New York: New Press.

Fuchs, C. (2014), Digital Labour and Karl Marx. New York: Routledge.

Fuchs, C. (2016), 'Digital Labor and Imperialism', Monthly Review, 67 (8), 14.

Gandini, A. (2019), 'Labour Process Theory and the Gig Economy', Human Relations, 72 (6), 1039-1056.

Gereffi, G. (2011), 'Global Value Chains and International Competition', The Antitrust Bulletin, 56 (1), 37-56.

Gereffi, G. (2014), 'Global Value Chains in a Post-Washington Consensus World', Review of International Political Economy, 21 (1), 9-37.

Graham, M., Hjorth, I. \& Lehdonvirta, V. (2017), 'Digital Labour and Development: Impacts of Global Digital Labour Platforms and the Gig Economy on Worker Livelihoods', Transfer, 23 (2), 135-162.

Haidar, J. (2020), La configuración del proceso de trabajo en las plataformas de reparto en la Ciudad de Buenos Aires. Un abordaje multidimensional y multi-método (julio/ agosto de 2020), Informe de coyuntura No. 11, octubre 2020. Buenos Aires: IIGG.

Harvey, D. (2005), A Brief History of Neoliberalism. Oxford: Oxford University Press.

Huws, U. (2013), 'Working Online, Living Offline: Labour in the Internet Age', Work Organization, Labour and Globalization, 7 (1), 1-11.

ILO (2018), Women and Men in the Informal Economy: A Statistical Picture. Third Edition. Geneva: International Labour Office.

Johnston, H. (2020), 'Labour Geographies of the Platform Economy: Understanding Collective Organizing Strategies in the Context of Digitally Mediated Work', International Labour Review, 159 (1), 25-45.

Kalleberg, A. (2009), 'Precarious Work, Insecure Workers: Employment Relations in Transition', American Sociological Review, 74 (1), 1-22.

Kenney, M. \& Zysman, J. (2016), 'The Rise of the Platform Economy', Issues in Science and Technology, 32 (3), 61-69.

Keune, M. \& Pedaci, M. (2020), 'Trade Union Strategies Against Precarious Work: Common Trends and Sectoral Divergence in the EU', European Journal of Industrial Relations, 26 (2), 139-155.

Langley, P. \& Leyshon, A. (2017), 'Platform Capitalism: The Intermediation and Capitalisation of Digital Economic Circulation', Finance and Society, 3 (1), 11-31.

Lepadatu, D. \& Janoski, T. (2020), Framing and Managing Lean Organizations in the New Economy. London: Routledge.

Marx, K. (2018), Capital. A Critique of Political Economy, Volume I, Book I. Champaign, IL: Modern Barbarian Press.

Möhlmann, M. \& Zalmanson, L. (2017), 'Hands on the Wheel: Navigating Algorithmic Management and Uber Drivers' Autonomy'. International Conference on Information Systems (ICIS 2017), Seoul. Available at: https:/www.researchgate.net/publication/ 319965259_Hands_on_the_wheel_Navigating_algorithmic_management_and Uber_drivers\%27_autonomy

Moore, P. V. \& Joyce, S. (2020), 'Black Box or Hidden Abode? The Expansion and Exposure of Platform Work Managerialism', Review of International Political Economy, 27 (4), 926-948. 
Pasquale, F. (2015), The Black Box Society: The Secret Algorithms That Control Money and Information. Cambridge, MA: Harvard University Press.

Peck, J. (2013), 'Explaining (with) Neoliberalism', Territory, Politics, Governance, 1 (2), 132-157.

Rose, N. (1999), Powers of Freedom. Reframing Political Thought. Cambridge: Cambridge University Press.

Rosenblat, A. \& Stark, L. (2016), 'Algorithmic Labor and Information Asymmetries: A Case Study of Uber's Drivers', International Journal of Communication, 10, 3758-3784.

Shapiro, A. (2018), 'Between Autonomy and Control: Strategies of Arbitrage in the “On-Demand" Economy', New Media \& Society, 20 (8), 2954-2971.

Silver, B. (2003), Forces of Labor: Workers' Movements and Globalization Since 1870. Cambridge: Cambridge University Press.

Soriano, C. \& Cabañes, J. (2020), 'Entrepreneurial Solidarities: Social Media Collectives and Filipino Digital Platform Workers', Social Media + Society. DOI: $10.1177 / 2056305120926484$

Srnicek, N. (2016), Platform Capitalism. Cambridge: Polity Press.

Standing, G. (2011), The Precariat: The New Dangerous Class. London: Bloomsbury.

Standing, G. (2016), The Corruption of Capitalism: Why Rentiers Thrive and Work Does Not Pay. Hull: Biteback Publishing.

Streeck, W. (2017), How Will Capitalism End? London and New York: Verso.

van der Zwan, N. (2014), 'Making Sense of Financialization', Socio-Economic Review, $12(1), 99-129$.

van Doorn, N. (2017), 'Platform Labor: On the Gendered and Racialized Exploitation of Low-Income Service Work in the "On-Demand" Economy', Information, Communication \& Society, 20 (6), 898-914.

van Doorn, N. \& Badger, A. (2020), 'Platform Capitalism's Hidden Abode: Producing Data Assets in the Gig Economy', Antipode. DOI: 10.1111/anti.12641

van Doorn, N., Ferrari, F. \& Graham, M. (2020), 'Migration and Migrant Labour in the Gig Economy: An Intervention (June 8, 2020)'. Available at SSRN: https://ssrn .com/abstract $=3622589$

Vercellone, C. (2020), 'Prólogo. Tiempos y destiempos de la ley del valor/plusvalía', in P. Miguez (ed.), Trabajo y valor en el capitalismo contemporáneo. Reflexiones sobre la valorización del conocimiento. Los Polvorines: Universidad Nacional de General Sarmiento, pp. 11-22.

Xia, H., Wang, Y., Huang, Y. \& Shah, A. (2017), “"Our Privacy Needs to be Protected at All Costs”: Crowd Workers' Privacy Experiences on Amazon Mechanical Turk', Proceedings of the ACM on Human-Computer Interaction, 1 (2), article 113. 